\title{
Nuevo ecosistema comunicativo digital: El consumidor
}

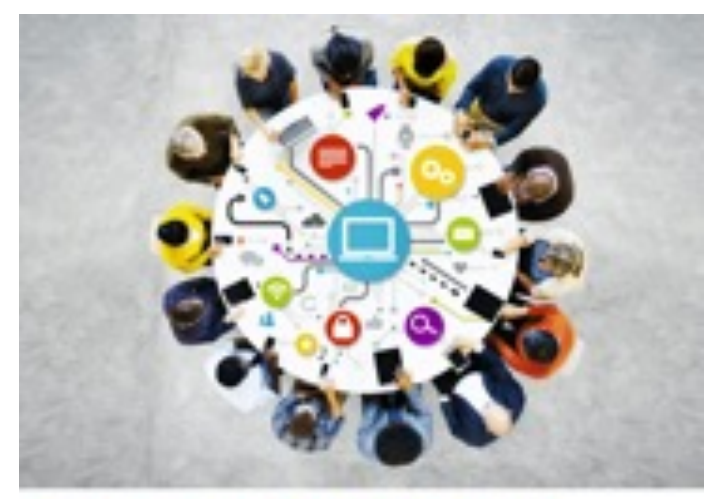

La comunicación en el escenario digital

Actualidad, retos y prospectiras

P Pearson

\section{La comunicación en el escenario digital}

Luis Miguel Romero Rodríguez y Diana

Elizabeth Rivera Rogel (Coordinadores)

Pearson Educación de Perú y la

Universidad Técnica Particular de Loja

$\overline{7} \overline{6} 3$ páginas

Reseña por Juan Carlos Figuereo Benítez

DOI: http://dx.doi.org/10.12795/Ambitos.2019.i46.14

Internet y los dispositivos digitales nos han cambiado la vida en todos los sentidos. La innovación ha permitido que vivamos actualmente rodeados de aparatos interconectados que han promovido, gracias al desarrollo tecnológico y las comunicaciones, entre otras cosas, que nos comuniquemos de otra forma. En este sentido, la comunicación no se ha quedado atrás, los avances tecnológicos e Internet han supuesto una transformación en el sistema de comunicación clásico y se han

\section{Forma de citar:}

Figuereo Benítez, J. C. (2019). Nuevo ecosistema comunicativo digital: El consumidor. Ámbitos. Revista Internacional de Comunicación 46, pp. 261-263. doi: 10.12795/Ambitos.2019.i46.14 
instaurado en las sociedades unos nuevos parámetros de los procesos comunicativos en los que el consumidor es el centro del proceso.

En el prólogo de la obra, Ignacio Aguaded, catedrático de la Universidad de Huelva (España) y editor-jefe de la revista Comunicar, afirma que el libro "sitúa magistralmente la complejidad de este momento en el devenir de la comunicación en el ecosistema digital", reconoce que "el panorama de la obra es poliédrico y abierto, como el ecosistema comunicativo digital sobre el que trata de ofrecer luces y referentes" y defiende que el periodismo no queda al margen de este impacto.

La obra, que se presenta en un total de 25 capítulos, recoge las reflexiones y las distintas miradas teóricas de más de 60 expertos iberoamericanos de la Comunicación de diferentes universidades para mostrar una realidad reciente en la que el consumidor es el quid de la cuestión. El libro capitular está a su vez subdividido en cinco grandes bloques temáticos.

De este modo, el primero, a modo de introducción, comienza con las miradas teóricas al ecosistema digital y la convergencia mediática, pone el foco en el consumidor como elemento clave en el proceso, los nuevos paradigmas, el periodismo, las redes virtuales, nuevas narrativas y estructuras. Cobran especial relevancia la Web 4.0, la Web Social, las identidades, las redes sociales digitales y las prácticas híbridas que la comunicación digital permiten. Define la transformación de la radio, la televisión e Internet, la llegada de las plataformas digitales y de las apps.

El segundo bloque trata sobre el presente y futuro de la profesión periodística en el ecosistema digital, señalando la importancia de la revolución de Internet y los medios digitales en Iberoamérica en los últimos veinte años. También se comparten reflexiones sobre las estructuras de la información, los conglomerados mediáticos digitales, el nuevo periodismo y las nuevas narrativas. Para terminar este apartado, varios expertos profundizan sobre la desinformación y la postverdad en los medios digitales.

El tercero analiza las comunicaciones en las organizaciones, concretamente aspectos tan importantes en este ámbito como el marketing y el posicionamiento. Se explican otros conceptos como la marca 3.0, la identidad corporativa, las narrativas transmedia, el storytelling, los influencers, el lead generation y la racionalidad social.

El cuarto se adentra en los medios digitales como espacios de ocio y entretenimiento que se llevan a cabo en las plataformas gamificadas, desarrolladas por las TIC y las TAC. Se describen también las formas de comunicación y educación entre los millennials, la Machine Learning, el discurso emocional y el infoentretenimiento digital. 
Y, en último lugar, el quinto bloque versa sobre la prospectiva de la comunicación digital, el panorama publicitario internacional y las tecnologías cognitivas. Nuevos anglicismos han llegado a nuestras vidas para quedarse, como por ejemplo el Big Data y el Augmented Data, en los que los autores ponen el foco. La comunicación en el escenario digital culmina con unas consideraciones acerca de las empresas ante este nuevo contexto, la participación del usuario, el futuro de la profesión periodística y el estudio y la praxis de la comunicación.

En definitiva, los autores debaten en este libro sobre la actualidad, los retos y las prospectivas de la comunicación en este nuevo marco a través de sus propias visiones profesionales, transdisciplinares y transcontinentales, de forma que se complementan para estructurar un manual que pretende ser material de consulta, pero también guía de discusión y reflexión para sus lectores.

Estamos ante una obra de recomendada lectura y consulta para estudiantes e investigadores de la materia que quieran, más allá de teorías obsoletas, descubrir en qué fase de la evolución y el progreso está la comunicación en la era digital actual, sus luces y sus sombras, en la que el consumidor ya no es un sujeto pasivo ni un mero receptor, sino que participa de forma activa en el propio producto. 